\title{
Waste Nutrient Solution as an Alternative Fertilizer in Curled Mallow Cultivation
}

\author{
Chungkeun Lee ${ }^{1}$, Dong Sub Kim ${ }^{2}$, Yurina Kwack ${ }^{3} \&$ Changhoo Chun ${ }^{1,4}$ \\ ${ }^{1}$ Department of Plant Science, Seoul National University, Seoul, Korea \\ ${ }^{2}$ Department of Plant Science, University of California Davis, Davis, California, USA \\ ${ }^{3}$ Division of EcoDivision of Eco-friendly Horticulture, Yonam College, Cheonan, Korea \\ ${ }^{4}$ Research Institute of Agriculture and Life Sciences, Seoul National University, Seoul, Korea \\ Correspondence: Changhoo Chun, Department of Plant Science, Seoul National University, Seoul 151-921, Korea. \\ Tel: 82-2-880-4567. E-mail: changhoo@snu.ac.kr
}

\author{
Received: October 2, $2019 \quad$ Accepted: January 4, $2020 \quad$ Online Published: February 15, 2020 \\ doi:10.5539/jas.v12n3p55 URL: https://doi.org/10.5539/jas.v12n3p55
}

\begin{abstract}
To determine the feasibility of reusing waste nutrient solution as an alternative fertilizer for vegetable production, we investigated the growth and shoot nutrient content of curled mallows (Malva verticillata L.) irrigated with tap water ( $\left.\mathrm{pH} 7.8, \mathrm{EC}: 0.5 \mathrm{dS} \cdot \mathrm{m}^{-1}\right)$, nutrient solution $\left(\mathrm{pH} 5.7, \mathrm{EC}: 2.7 \mathrm{dS} \cdot \mathrm{m}^{-1}\right)$ and waste nutrient solution $(\mathrm{pH} 5.0$, EC: $2.2 \mathrm{dS} \cdot \mathrm{m}^{-1}$ in average) collected from plant factories. Three waste nutrient solutions were applied in sequential order to a waste nutrient solution treatment and mineral compositions of irrigation solutions were analyzed. We measured the total number of leaves, fresh and dry weight, chlorophyll content (SPAD value) and total phenolic content of curled mallow shoots and analyzed shoot and soil nutrient content using inductively coupled plasma-optical emission spectrometer (ICP-OES). Curled mallows were harvested twice during the cultivation. Curled mallows irrigated with waste nutrient solutions had a similar fresh weight (yield), total phenolic content and number of leaves compared to those grown with fresh nutrient solution, and had higher fresh and dry weight, chlorophyll content (SPAD value) and percentage dry weight compared to those grown with tap water upon first and second harvest. The dry weight of curled mallows grown in waste nutrient solution was lower than that of plants grown in nutrient solution on first harvest, but there was no significant difference between the waste nutrient solution and nutrient solution groups on second harvest. Curled mallows irrigated with nutrient solution and waste nutrient solution showed similar mineral content. These results suggest that waste nutrient solution in curled mallow cultivation could be reused and provide more efficient and sustainable nutritional solutions that improve the productive yields of crops in the agriculture sector.
\end{abstract}

Keywords: fertigation, hydroponics, mineral absorption, nutrient content, greenhouse

\section{Introduction}

In recent years, hydroponic systems have become increasingly popular in the greenhouse industry (Savvas \& Gruda, 2018). The hydroponic crop production increased up to approximately 30,000 ha in 2015 (Simpkins, Jungers, \& Stimmel, 2015) and the hydroponic market is expected to have annual growth rate of $6.5 \%$ from 2018 to 2023 (Mordor Intelligence, 2018). As a consequence of the development of the hydroponics industry, the amount of waste nutrient solution discharged from hydroponic systems has also increased.

Discharged waste nutrient solution generally contains high concentrations used to increase crop yield. Nutrient solutions in closed hydroponic systems are periodically dumped during crop cultivation to prevent accumulation of salt ions, which can cause serious growth disorders (Sánchez-Guerrero, Lorenzo, Medrano, Baille, \& Castilla, 2009; Savvas, Meletiou, Margariti, Tsirogiannis, \& Kotsiras, 2005; Savvas et al., 2007) and plant diseases that can reduce crop yield and even eliminate all crops at once (Badgery-Parker, 2002; Grewal, Maheshwari, \& Parks, 2011). Zekki, Gauthier, and Gosselin (1996) also noted that prolonged recycling of nutrient solution can cause yield reduction in closed hydroponic systems. In addition, the volume and concentration of applied nutrient solution are generally higher than those required for plant growth in order to satisfy variability in irrigation equipment and to maximize crop yield (Grasselly et al., 2005; Rouphael \& Colla, 2009). 
Increasing amounts of nutrient rich waste solution from hydroponic systems pose a major environmental concern. Waste nutrient solution contains high concentrations of nitrogen and phosphorus and discharge can lead to the eutrophication of lagoon water and groundwater, causing oxygen depletion and toxin release through algal blooms, severely contaminating drinking water (Kumar \& Cho, 2014; Prystay \& Lo, 2001). Grewal et al. (2011) reported that approximately $60 \%$ of irrigated nutrient solution could be discharged as drainage water in an open hydroponic system and that reusing waste nutrient solution could help reduce environmental pollution.

Many studies have explored crop cultivation using municipal and domestic wastewater (Cirelli et al., 2012; Urbano, Mendoca, Bastos, \& Souza, 2017) and animal manure vermicompost (Gutiérrez-Miceli et al., 2007; Mowa, Akundabweni, Chimwamurombe, Oku, \& Mupambwa, 2017). In these studies, reusing the nutrients from waste had no negative effects on crop growth. However, only a few studies have examined the potential use of waste nutrient solution from plant cultivation in hydroponic systems as an appropriate irrigation solution. Furthermore, most of the studies on waste nutrient solution from hydroponics focused on the different effects of irrigation solutions on plant growth, but did not analyze the mineral content of plant tissue (Choi, Lee, \& Ok, 2011a; Choi et al., 2011b; Zhang, Kang, \& Kim, 2006), nor did they include detailed analysis of soil and plant nutrient content (Kim et al., 2000; Park, Kim, Yoo, Ok, \& Yang, 2005; Zhang, Lim, Kang, \& Kim, 2010).

Curled mallow (M. verticillata) is a leafy vegetable popular in East Asia and known for its several pharmaceutical effects (Ko et al., 2019). The plants were harvested twice in this experiment to compare the effects of irrigation solutions over cultivation time. The objectives of this study were to investigate the growth and nutrient content of curled mallows irrigated with waste nutrient solution, nutrient solution and tap water, and to confirm the feasibility of reusing waste nutrient solution as an alternative fertilizer in curled mallow cultivation.

\section{Material and Method}

\subsection{Plant Material and Growth Conditions}

Curled mallows (Malva verticillata L.) were grown from May 23 to August 1, 2014 at the experimental farm of Seoul National University (Suwon, Korea, $37.3^{\circ} \mathrm{N}, 127.0^{\circ} \mathrm{E}$ ). During the cultivation period in a greenhouse, the mean air temperature was approximately $24^{\circ} \mathrm{C}$ and maximum and minimum air temperatures were 29 and $21{ }^{\circ} \mathrm{C}$ at the experimental site (Figure 1).

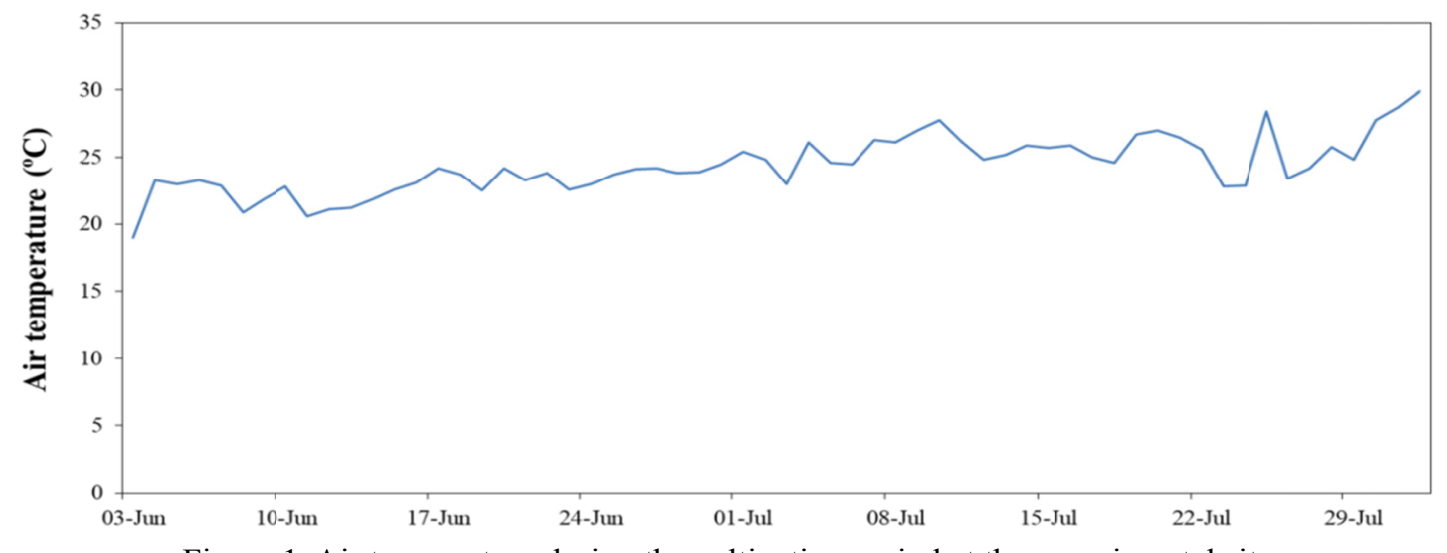

Figure 1. Air temperature during the cultivation period at the experimental site

The seedlings were grown in the plant factory using fluorescent lamps as a light source (air temperature during the photo/dark period, $25 / 21{ }^{\circ} \mathrm{C}$; photo/dark period, $16 / 8 \mathrm{~h}$; light intensity, PPF $210 \mu \mathrm{mol} \cdot \mathrm{m}^{-2} \cdot \mathrm{s}^{-1} ; \mathrm{CO}_{2}$ concentration, $750 \mu \mathrm{mol} \cdot \mathrm{mol}^{-1}$ ) for 11 days in 128 -cell trays. Seedlings were selected randomly and five plants were transplanted to each plastic pot $(180 \times 600 \times 150 \mathrm{~mm})$ filled with commercial soil on June 3 . Pots were drip-irrigated with the same amount on each treatment when necessary considering the growth environment (Figure 2). 


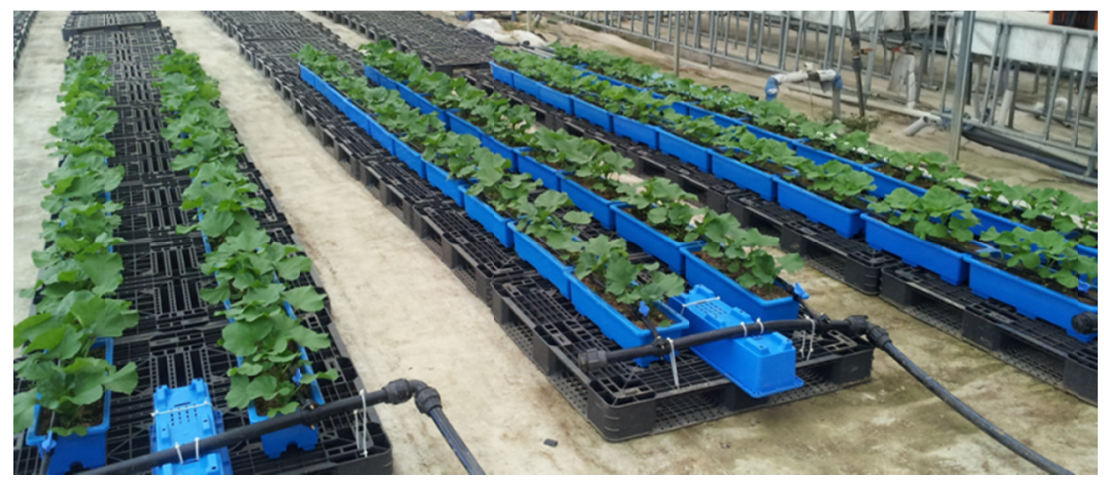

Figure 2. Curled mallows drip-irrigated with three irrigation solutions in a greenhouse

Nutrient solution (NS), waste nutrient solution (WNS) and tap water (TW) were used as the irrigation solution. The nutrient solution was prepared according to the Japanese standard 'Enshi' formula, which is widely used for vegetable crop cultivation (Yamasaki, Suzuki, \& Shinohara, 1976). Waste nutrient solutions were collected from three different plant factories using a deep flow technique (DFT) hydroponic system cultivating spinach. Nutrient solution was applied on June 10 in NS treatment and three waste nutrient solutions were applied in sequential order from June 10 to 19 (waste nutrient solution 1), June 20 to July 20 (waste nutrient solution 2) and July 21 to August 1 (waste nutrient solution 3), respectively, to WNS treatment.

The $\mathrm{pH}$ and electrical conductivity (EC) levels of irrigation solution were measured with a $\mathrm{pH}$ and EC meter (D-54, Spectrum Technologies, Inc., Aurora, IL, USA) and the ion concentrations $\left(\mathrm{NO}_{3}, \mathrm{NH}_{4}, \mathrm{PO}_{4}, \mathrm{~K}, \mathrm{Ca}, \mathrm{Mg}\right.$, $\mathrm{Na}, \mathrm{Cl}$ and $\mathrm{SO}_{4}$ ) were determined via ion chromatography (ICS-3000, Dionex, Sunnyvale, CA, USA) equipped with a Dionex IonPac CS12A $4 \mathrm{~mm} \times 250 \mathrm{~mm}$ column (cation) and AS20 $4 \mathrm{~mm} \times 250 \mathrm{~mm}$ column (anion). The cation and anion composition of the irrigation solution were calculated as ratios of molar concentration and positioned as a single point in trilinear coordinates using the method of De Rijck and Schrevens (1998).

\subsection{Growth Analysis}

Curled mallows were harvested on July 1 (28 days after transplanting, DAT, first harvest) and again on August 1 (59 DAT, second harvest) after the shoot had regenerated. Plants were harvested $20 \mathrm{~mm}$ from the bottom of the stem and all the remaining leaves of the curled mallows were removed at the first harvest in order to provide similar conditions for the three different treatment groups in the second cultivation. We selected nine plants randomly and measured the chlorophyll index using a chlorophyll meter (SPAD-502, Minolta Co., Ltd., Tokyo, Japan). The total number of leaves and fresh and dry weight were also recorded and the percentage dry weight was calculated as the ratio between fresh weight and dry weight.

\subsection{Chemical Analysis}

Soil and plant samples were oven-dried at $80{ }^{\circ} \mathrm{C}$ for at least $72 \mathrm{~h}$ to analyze nutrient content. Nitrogen was measured with a Kjeldahl nitrogen analyzer (Kjeltic Auto 1038 system, Tecator AB, Hoganas, Sweden) using the Kjeldahl method (Kjeldahl, 1883) and $\mathrm{P}, \mathrm{K}, \mathrm{Ca}$ and $\mathrm{Mg}$ were analyzed using an inductively coupled plasma-optical emission spectrometer (ICP-OES) (ICP-730ES, Varian, Mulgrave, Australia) with a modified method from Adesemoye, Torbert, and Kloepper (2008).

For soil analysis, a modified Mehlich 1 (double acid) extraction method was used (Mehlich, 1953). Each soil sample was dried and sieved using a $0.60 \mathrm{~mm}$ stainless steel sieve. After $1.4 \mathrm{~g}$ of sieved soil and $12.5 \mathrm{~mL}$ of Mehlich 1 extraction solution $\left(0.05 \mathrm{~mol} \cdot \mathrm{L}^{-1} \mathrm{H}_{2} \mathrm{SO}_{4}+0.05 \mathrm{~mol} \cdot \mathrm{L}^{-1} \mathrm{HCl}\right)$ was added to a $50 \mathrm{~mL}$ extraction flask, it was shaken for $5 \mathrm{~min}$ on a reciprocating shaker (HB-203L, Hanbaek Scientific Co., Bucheon, Republic of Korea) at 180 oscillations $\cdot \mathrm{min}^{-1}$. The solution was filtered through Whatman No. 2 filter paper and an extra $1.5 \mathrm{~mL}$ of Mehlich 1 extraction solution was added during the filtering process. The filtrate was sent to National Instrumentation Center for Environmental Management (NICEM, Seoul National University, Seoul, Korea) and analyzed using ICP-OES technique to determine the mineral composition of the soil sample.

For plant analysis, $0.5 \mathrm{~g}$ of fine dry powder of the leaf and stem tissues was placed into a $50 \mathrm{~mL}$ beaker, covered with aluminum foil, and was heated to $450{ }^{\circ} \mathrm{C}$ for $4 \mathrm{~h}$ in a muffle furnace (SH MF2C, Samheung Energy Inc., Sejong, Korea). After heating, $10 \mathrm{~mL}$ of $1 \mathrm{~mol} \cdot \mathrm{L}^{-1} \mathrm{HNO}_{3}$ was added to the plant ash and evaporated slowly on a hot plate until it dried. Then, $10 \mathrm{~mL}$ of $1 \mathrm{~mol} \cdot \mathrm{L}^{-1} \mathrm{HCl}$ was added to the beaker, heated almost to boiling, and transferred to a $100 \mathrm{~mL}$ volumetric flask. The beaker was washed three times with small amounts of water to 
minimize mineral loss, and water was added until the amount of solution in the flask reached $100 \mathrm{~mL}$. The solution was filtered through Whatman No. 2 filter paper and the filtrate was analyzed by NICEM (Seoul National University, Seoul, Korea) using ICP-OES to determine the mineral composition of the plant sample.

The total amount of phenolic compounds in each plant sample was determined using the Folin-Ciocalteu assay (Slinkard \& Singleton, 1977). First, $0.2 \mathrm{~g}$ of the fine dry powder was mixed with $12 \mathrm{~mL}$ of extraction solution (acetone:methanol:water:acetic acid $=40: 40: 20: 1)$ in a $50 \mathrm{~mL}$ conical centrifuge tube for $10 \mathrm{~s}$ using a homogenizer (PT-MR2100, Kinematica AG, Lucerne, Switzerland). The tube was kept at $60^{\circ} \mathrm{C}$ for $1 \mathrm{~h}$ and more extraction solution was added until the amount of solution in the tube reached $20 \mathrm{~mL}$, followed by filtration. Subsequently, $1 \mathrm{~mL}$ of the filtrate was mixed with $1 \mathrm{~mL}$ of $10 \%$ Folin-Ciocalteu phenol reagent and $1 \mathrm{~mL}$ of $7.5 \% \mathrm{Na}_{2} \mathrm{CO}_{3}$ solution, in sequence. After incubation for $2 \mathrm{~h}$ at room temperature, absorbance was determined using a UV visible spectrophotometer (UV-2550, Shimadzu Corp., Kyoto, Japan) at $726 \mathrm{~nm}$. The same procedure was repeated with garlic acid solutions $\left(0,0.1,0.2\right.$ and $\left.0.5 \mathrm{mg} \cdot \mathrm{mL}^{-1}\right)$ and a standard curve was obtained.

\subsection{Statistical Analysis}

SAS version 9.2 software (SAS Institute INC., Cary, NC, USA) was used for analysis of variance (ANOVA). Differences among treatment means were separated by the Fisher's least significant difference (LSD) test at $P<$ 0.05 .

\section{Results and Discussion}

\subsection{Quality of Irrigation Solution}

The mineral composition of nutrient solution, waste nutrient solution and tap water used for curled mallow irrigation are shown in Table 1. Waste nutrient solution generally has low EC and $\mathrm{pH}$ levels and high $\mathrm{Na}, \mathrm{Cl}$ and $\mathrm{SO}_{4}$ ion concentrations compared to regular nutrient solution (Kumar \& Cho, 2014). In this experiment, all waste nutrient solutions applied to WNS treatment group had lower $\mathrm{EC}$ and $\mathrm{pH}$ levels and $\mathrm{NO}_{3}, \mathrm{NH}_{4}, \mathrm{PO}_{4}$ and $\mathrm{K}$ concentration compared to nutrient solution, while $\mathrm{Mg}, \mathrm{Na}, \mathrm{Cl}$ and $\mathrm{SO}_{4}$ concentrations were higher in waste nutrient solution. This corresponds with the results of Zekki et al. (1996) and Zhang et al. (2010), who reported $\mathrm{Mg}, \mathrm{Na}, \mathrm{Cl}$ and $\mathrm{SO}_{4}$ concentration increased in the waste nutrient solution as the crops grew.

Table 1. The $\mathrm{pH}, \mathrm{EC}$ and ion concentrations of nutrient solution, waste nutrient solution and tap water.

\begin{tabular}{|c|c|c|c|c|c|c|c|c|c|c|c|}
\hline \multirow{2}{*}{ Treatment } & \multirow{2}{*}{$\mathrm{pH}$} & \multirow{2}{*}{$\mathrm{EC}\left(\mathrm{dS} \cdot \mathrm{m}^{-1}\right)$} & \multicolumn{9}{|c|}{ Ion concentration $\left(\mathrm{mg} \cdot \mathrm{L}^{-1}\right)$} \\
\hline & & & $\mathrm{NO}_{3}$ & $\mathrm{NH}_{4}$ & $\mathrm{PO}_{4}$ & $\mathrm{~K}$ & $\mathrm{Ca}$ & $\mathrm{Mg}$ & $\mathrm{Na}$ & $\mathrm{Cl}$ & $\mathrm{SO}_{4}$ \\
\hline Nutrient solution & 5.7 & 2.7 & 1236.4 & 80.9 & 358.9 & 322.9 & 179.2 & 24.5 & 12.8 & 9.8 & 74.3 \\
\hline Waste nutrient solution 1 & 5.4 & 2.6 & 1178.6 & 41.3 & 277.8 & 299.3 & 194.2 & 25.9 & 32.6 & 14.1 & 89.1 \\
\hline Waste nutrient solution 2 & 4.6 & 2.0 & 934.5 & 19.6 & 145.2 & 252.8 & 166.3 & 41.6 & 17.0 & 11.2 & 137.8 \\
\hline Waste nutrient solution 3 & 5.0 & 2.0 & 806.8 & 13.7 & 82.7 & 226.9 & 144.6 & 42.9 & 15.5 & 13.1 & 145.0 \\
\hline Tap water & 7.8 & 0.5 & 4.9 & n. $\mathrm{d}^{\mathrm{z}}$ & n.d & 2.0 & 8.8 & 1.2 & 8.5 & 17.0 & 13.4 \\
\hline
\end{tabular}

Note. ${ }^{\mathrm{Z}}$ Not detected.

The chemical composition of nutrient solutions is determined not only based on $\mathrm{EC}$ and $\mathrm{pH}$, but also the relative ion proportions (Steiner, 1961). In this experiment, the cation and anion composition of three waste nutrient solutions were similar to that of nutrient solution (Figure 3). The position of each point within an equilateral triangle was determined based on cation $(\mathrm{K}, \mathrm{Mg}$ and $\mathrm{Ca})$ and anion $\left(\mathrm{NO}_{3}, \mathrm{SO}_{4}\right.$ and $\left.\mathrm{PO}_{4}\right)$ ratios, and the length of the perpendiculars from the point to each side of the triangle corresponded to the proportion of each ion (De Rijck \& Schrevens, 1998). The average Euclidean distance between the nutrient solution and waste nutrient solution was 0.07 for cation and anion composition, while that between nutrient solution and tap water was 0.47 and 0.63 , respectively, in trilinear coordinates. This suggests that ion proportions of waste nutrient solutions from closed hydroponic spinach cultivation systems would not have negative effects on curled mallow cultivation in that the relative ion ratios of waste nutrient solutions were similar to those of 'Enshi' nutrient solution which ion balance was designed for various vegetables in all growth stages (Park \& Kim, 1998). 


\section{Cation composition}

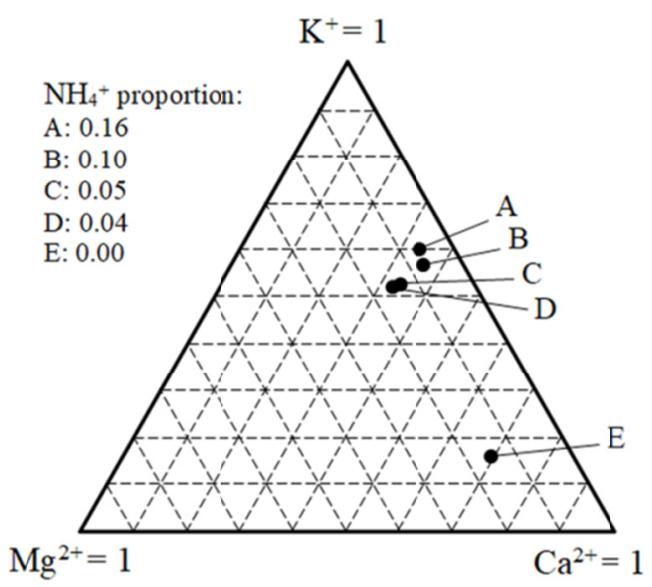

\section{Anion composition}

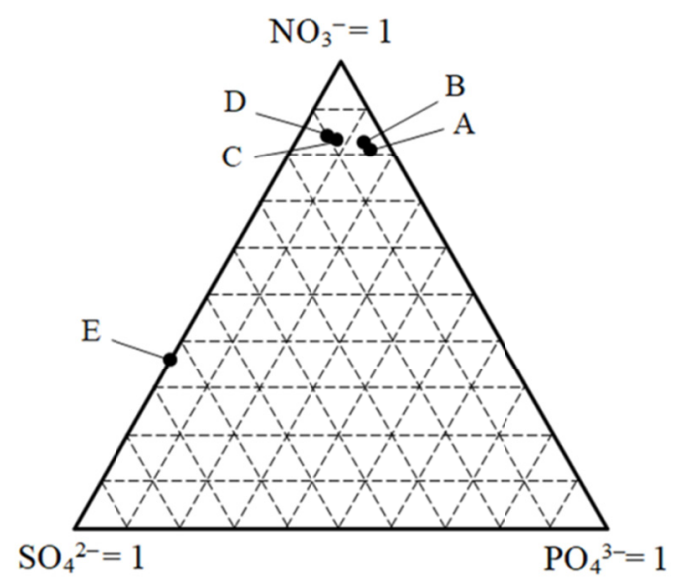

Figure 3. Cation and anion composition of the irrigation solutions. A: Nutrient solution; B: Waste nutrient solution 1; C: Waste nutrient solution 2; D: Waste nutrient solution 3; E: Tap water

According to Van Os (1999) and Tüzel et al. (2000), a closed hydroponic system provides approximately $20-40 \%$ less irrigation water and nutrients to plant than an open hydroponic system, but with a longer absorption time. Assuming that crops absorb the same amount of nutrients in the two different hydroponic systems, waste nutrient solution discharged from closed hydroponics would contain fewer minerals than open hydroponics. However, the waste nutrient solution in this experiment contained $\mathrm{NO}_{3}, \mathrm{PO}_{4}$ and $\mathrm{K}$ concentrations that represented 79,47 and $80 \%$ of the concentrations in the applied nutrient solution, respectively, which seemed relatively high for effluents from closed hydroponic systems. This could be because the waste nutrient solution in this experiment was discharged from a closed hydroponic system at an early stage of the cultivation period to prevent salt accumulation, which could reduce plant growth and restrict P, K and Mg content in leaves (Savvas et al., 2005). In addition, according to Medrano et al. (2005) and Terebayashi, Takii, and Namiki (1991), every waste nutrient solution has a different mineral concentration and composition because different kinds of plants absorb different amounts of minerals throughout their growth in hydroponic systems. Grewal et al. (2011) also mentioned that the efficiency of hydroponic systems could vary depending on their design and the way the water and nutrient applications are managed.

\subsection{Plant Growth}

The number of leaves of curled mallows irrigated with waste nutrient solution did not vary significantly from that of nutrient solution and tap water upon first harvest (Figure 4A). Upon second harvest, the number of leaves in the WNS group (8.7 per plant) did not differ significantly compared with the NS group, but was $39.3 \%$ higher than that in the TW group (6.2 per plant) (Figure 4F).

The chlorophyll content (SPAD value) differed significantly among NS, WNS and TW groups at the first and second harvests (Figures 4B and 4G). WNS group plants had 8.4 and $6.7 \%$ lower SPAD value (44.0 and 40.5) compared to NS plants (48.0 and 43.4), while the SPAD value in WNS plants was higher by 18.4 and $22.6 \%$ compared to that in TW plants (37.1 and 33.0) upon first and second harvest, respectively. Several studies have shown that chlorophyll content positively correlated with leaf N content (Chapman \& Barreto, 1997; Nageswara Rao, Talwar, \& Wright, 2001) and Mg content (Ding et al., 2008). In our study, curled mallows irrigated with waste nutrient solution had higher $\mathrm{N}$ and $\mathrm{Mg}$ content compared to those irrigated with tap water, which corresponded well with previous research, but curled mallows irrigated with nutrient solution showed similar $\mathrm{N}$ content and lower Mg content compared to those irrigated with waste nutrient solution, although the SPAD value was higher in the NS group (Table 2). This could be due to the high salt concentration of waste nutrient solution, which could lead to salt stress in chlorophyll synthesis (Santos, 2004), but further investigation of this relationship is needed. 
First harvest
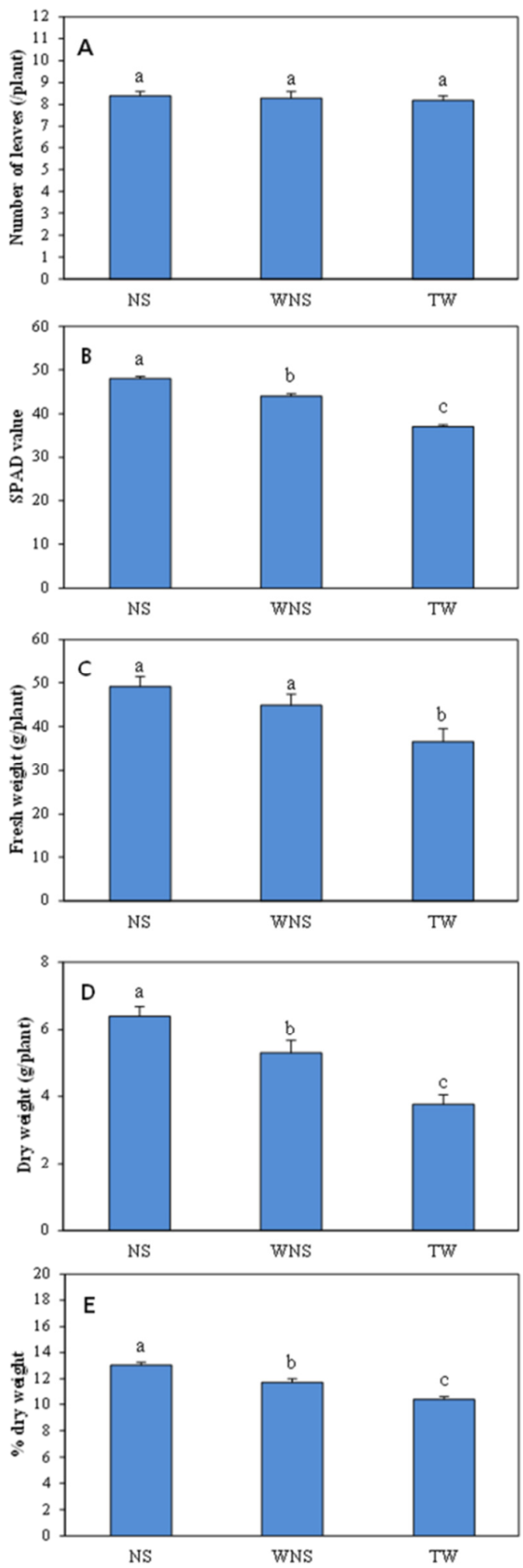

Second harvest
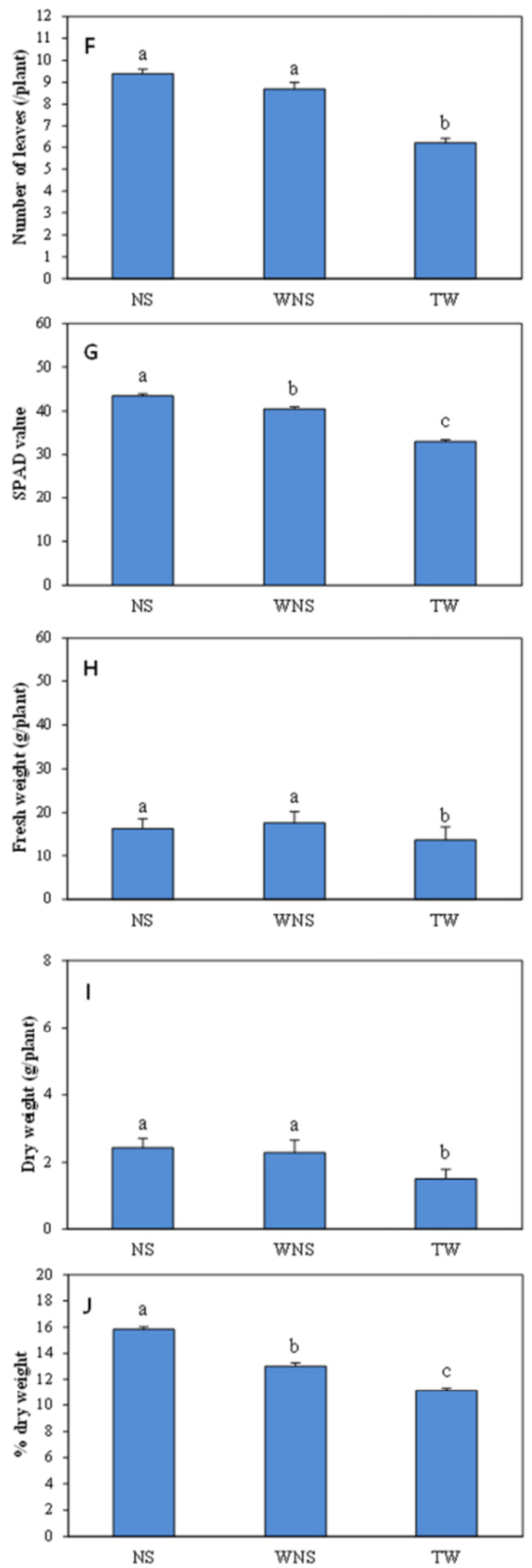

Figure 4. The number of leaves (A and F), SPAD value (B and G), fresh weight (C and H), dry weight (D and I) and percentage dry weight (E and J) of curled mallows in the NS, WNS and TW groups at the first and second harvest. NS: treatment with nutrient solution; WNS: treatment with three waste nutrient solutions; TW: treatment with tap water. Means within the same column followed by the same letter are not significantly different at the $P=0.05$ level of probability based on Fisher's least significant difference (LSD) statistics 
Table 2. Nutrient content of curled mallows irrigated with nutrient solution, waste nutrient solution and tap water at the first and second harvest

\begin{tabular}{llllll}
\hline Treatment & $\mathrm{N}(\%)$ & $\mathrm{P}\left(\mathrm{mg} \cdot \mathrm{g}^{-1}\right)$ & $\mathrm{K}\left(\mathrm{mg} \cdot \mathrm{g}^{-1}\right)$ & $\mathrm{Ca}\left(\mathrm{mg} \cdot \mathrm{g}^{-1}\right)$ & $\mathrm{Mg}\left(\mathrm{mg} \cdot \mathrm{g}^{-1}\right)$ \\
\hline First harvest & & & & & \\
Nutrient solution & $4.65 \mathrm{a}^{\mathrm{z}}$ & $7.80 \mathrm{a}$ & $64.18 \mathrm{a}$ & $18.56 \mathrm{a}$ & $2.93 \mathrm{~b}$ \\
Waste nutrient solution (1-3) & $4.31 \mathrm{a}$ & $7.91 \mathrm{a}$ & $63.36 \mathrm{a}$ & $20.05 \mathrm{a}$ & $3.55 \mathrm{a}$ \\
Tap water & $3.40 \mathrm{~b}$ & $4.64 \mathrm{~b}$ & $62.15 \mathrm{a}$ & $14.41 \mathrm{~b}$ & $3.25 \mathrm{ab}$ \\
\hline Second harvest & & & & \\
Nutrient solution & $4.15 \mathrm{ab}$ & $6.72 \mathrm{a}$ & $40.42 \mathrm{~b}$ & $24.29 \mathrm{ab}$ & $4.89 \mathrm{~b}$ \\
Waste nutrient solution (1-3) & $4.94 \mathrm{a}$ & $7.27 \mathrm{a}$ & $45.50 \mathrm{~b}$ & $26.84 \mathrm{a}$ & $5.77 \mathrm{a}$ \\
Tap water & $3.87 \mathrm{~b}$ & $6.65 \mathrm{a}$ & $59.00 \mathrm{a}$ & $20.37 \mathrm{~b}$ & $4.44 \mathrm{~b}$ \\
\hline
\end{tabular}

Note. ${ }^{\mathrm{z}}$ Means within the same column followed by the same letter are not significantly different at the $P=0.05$ level of probability based on Fisher's least significant difference (LSD) statistics.

The fresh weight of curled mallows irrigated with waste nutrient solution (44.8 and $17.6 \mathrm{~g})$ did not differ significantly from nutrient solution (49.1 and $16.3 \mathrm{~g}$ ), but was 22.9 and $28.7 \%$ higher compared to those irrigated with tap water ( 36.5 and $13.7 \mathrm{~g}$ ) upon first and second harvest (Figures 4C and 4H). The total yield (fresh weight per unit area on first and second harvest) of curled mallows in the WNS group was $4.5 \%$ lower compared to that in the NS group, but was $24.5 \%$ higher compared to the TW group. This suggests that crops cultivated with waste nutrient solution are economically equivalent to those cultivated with nutrient solution, and economically superior to the use of tap water.

The dry weight of the WNS group (5.3 g) was 17.4\% lower than that of NS (6.4 g) upon first harvest, but there was no significant difference between the two treatments upon second harvest, which implies a relative increase in the dry weight of WNS compared to NS during the period between harvest stages (Figures 4D and 4I). The dry weight indicates the amount of surplus carbohydrates from photosynthesis and respiration, and the results suggest that curled mallows irrigated with waste nutrient solution can accumulate similar amounts of carbohydrates to those irrigated with nutrient solution by second harvest. As the nutrient uptake of plants can change with plant growth stage, the nutrient requirements might decrease with increasing plant age and thus the nutrient content of WNS could meet the requirements for plant growth after the first harvest. The curled mallows in the WNS group (5.3 and $2.3 \mathrm{~g}$ ) had 40.5 and 51.7\% higher dry weight compared to that of the TW group (3.8 and $1.5 \mathrm{~g}$ ) upon first and second harvest, respectively. Choi et al. (2011a) reported similar results for fresh and dry weights of Chinese cabbage irrigated with waste nutrient solution, which were similar or slightly lower than those irrigated with nutrient solution and similar or higher than those irrigated with groundwater 26 and 56 DAT. According to Kim et al. (2000), poinsettia irrigated with waste nutrient solution had higher fresh and dry weights of shoot compared to nutrient solution-irrigated groups. Park et al. (2005) also reported that red pepper (Capsicum annum L.) irrigated with hydroponic wastewater had a similar yield to those irrigated with nutrient solution and a more than $20 \%$ higher yield compared to tap water.

The percentage dry weight of curled mallows differed significantly among the three treatment groups (Figures $4 \mathrm{E}$ and $4 \mathrm{~J})$. The percentage dry weight in the WNS group (0.12) was $9.8 \%$ lower compared to the NS group (0.13) and higher by $13.2 \%$ compared to the TW group $(0.1)$ at the first harvest. Upon second harvest, the percentage dry weight of curled mallows in the WNS group (0.13) was $13.0 \%$ lower and $15.8 \%$ higher compared to the NS (0.15) and TW groups (0.11), respectively. This suggests that the percentage dry weight is positively correlated with SPAD value (Figures 4B and 4G) which generally correlates with photosynthesis. Jacobson (1945) reported a relationship between the percentage dry weight and photosynthesis, with higher rates of photosynthesis correlating with greater percentage dry weight in green leaves when compared leaves with chlorosis.

\subsection{Nutrient Content of Soil}

The nutrient content of the soil for WNS plants did not vary from that of NS plants in N and P at the first harvest (Table 3). Considering that the $\mathrm{N}$ and $\mathrm{P}$ concentrations of nutrient solution were higher than those of waste nutrient solution, similar residual mineral levels in the soil of the NS and WNS groups implies that NS plants absorbed more $\mathrm{N}$ and $\mathrm{P}$ compared to WNS plants. This could be confirmed based on the total nutrient content of curled mallow shoots, which was calculated by multiplying the average plant nutrient concentration (Table 2) and dry weight (Figures 4D and 4I), with the results showing 30.8 and $19.1 \%$ higher $\mathrm{N}$ and $\mathrm{P}$ content in the NS 
group compared to the WNS group, respectively. The soil nutrient content in the WNS group was $0.13 \%, 1.09$ $\mathrm{g} \cdot \mathrm{kg}^{-1}$ and $0.91 \mathrm{~g} \cdot \mathrm{kg}^{-1}$ higher in $\mathrm{N}, \mathrm{P}$ and $\mathrm{K}$ concentrations, respectively, compared to the TW group, but was 0.85 $\mathrm{g} \cdot \mathrm{kg}^{-1}$ lower in $\mathrm{K}$ concentration compared to the NS group on first harvest. The Ca concentration in the WNS group was lower than that in the NS group and higher than that in the TW group, while Mg concentration in the WNS group was the highest among the three treatments.

Table 3. Mean values ( \pm standard error) of nutrient content in soil before cultivation and after the first and second harvest.

\begin{tabular}{llllll}
\hline Treatment & $\mathrm{N}(\%)$ & $\mathrm{P}\left(\mathrm{g} \cdot \mathrm{kg}^{-1}\right)$ & $\mathrm{K}\left(\mathrm{g} \cdot \mathrm{kg}^{-1}\right)$ & $\mathrm{Ca}\left(\mathrm{g} \cdot \mathrm{kg}^{-1}\right)$ & $\mathrm{Mg}\left(\mathrm{g} \cdot \mathrm{kg}^{-1}\right)$ \\
\hline Commercial soil & 0.51 & 1.21 & 0.90 & 7.14 & 2.14 \\
\hline First harvest & & & & & \\
Nutrient solution & $0.54 \pm 0.01$ & $2.26 \pm 0.16$ & $2.65 \pm 0.55$ & $9.44 \pm 1.22$ & $1.78 \pm 0.29$ \\
Waste nutrient solution (1-3) & $0.56 \pm 0.00$ & $2.22 \pm 0.02$ & $1.80 \pm 0.13$ & $8.49 \pm 0.29$ & $2.51 \pm 0.46$ \\
Tap water & $0.43 \pm 0.02$ & $1.13 \pm 0.27$ & $0.88 \pm 0.04$ & $6.47 \pm 0.03$ & $1.73 \pm 0.08$ \\
\hline Second harvest & & & & & \\
Nutrient solution & $0.82 \pm 0.06$ & $6.25 \pm 0.36$ & $4.92 \pm 0.25$ & $15.60 \pm 1.05$ & $2.63 \pm 0.15$ \\
Waste nutrient solution (1-3) & $0.57 \pm 0.03$ & $2.72 \pm 0.48$ & $2.49 \pm 0.09$ & $8.81 \pm 0.78$ & $1.95 \pm 0.17$ \\
Tap water & $0.46 \pm 0.02$ & $0.28 \pm 0.01$ & $0.70 \pm 0.01$ & $5.24 \pm 0.00$ & $1.43 \pm 0.01$ \\
\hline
\end{tabular}

The soil mineral concentrations in the WNS group were lower compared to NS and higher compared to TW for all minerals analyzed upon second harvest. The N, P and K concentrations of soil in the WNS group were $0.25 \%$, $3.53 \mathrm{~g} \cdot \mathrm{kg}^{-1}$ and $2.43 \mathrm{~g} \cdot \mathrm{kg}^{-1}$ lower compared to NS, but $0.11 \%, 2.44 \mathrm{~g} \cdot \mathrm{kg}^{-1}$ and $1.78 \mathrm{~g} \cdot \mathrm{kg}^{-1}$ higher compared to TW, respectively. All soil mineral concentrations in the NS and WNS groups increased upon second harvest compared to first harvest except for $\mathrm{Mg}$ concentration in WNS. The observed increases in $\mathrm{N}, \mathrm{P}$ and $\mathrm{K}$ between the two harvest stages were 51.9, 176.7 and $85.6 \%$ in NS, while those in WNS were only $1.8,22.6$ and $38.4 \%$, respectively. The difference in soil mineral concentration between the two harvest stages indicates the amount of residual soil nutrient content after mineral absorption by plants in the second cultivation period, and the above results demonstrated that more nutrients were provided to the NS group than the plants needed, causing the accumulation of excess minerals in the soil (Ju, Kou, Christie, Dou, \& Zhang, 2007). The same was not seen for the WNS group. This suggests that using waste nutrient solution for irrigation instead of nutrient solution could decrease water pollution related to leaching of excess soil nutrients.

\subsection{Nutrient Content of Plant Samples}

Nutrient content per gram of curled mallows (leaf and stem tissues) irrigated with waste nutrient solution did not differ significantly from that of nutrient solution in $\mathrm{N}, \mathrm{P}, \mathrm{K}$ and $\mathrm{Ca}$ concentration upon first and second harvest (Table 2). This could be because waste nutrient solution with low $\mathrm{EC}$ and $\mathrm{pH}$ and high $\mathrm{Na}$ and $\mathrm{Cl}$ concentrations was buffered with minerals in the commercial soil. The commercial soil already contained a certain amount of minerals before irrigation and when waste nutrient solution was applied, minerals in both the solution and soil were mixed and provided to curled mallows. In addition, soil nutrients over the optimum concentration level could have affected plant nutrient content. When nutrients are provided in excess of the optimum concentration level, further mineral absorption is limited and plants cultivated within the nutrient sufficiency range contain similar mineral levels in their tissues (Campbell, 2000). In this experiment, even with a considerable excess of residual nutrients in the soil of the NS group on second harvest, curled mallows could not further absorb minerals due to having reached the optimum concentration level. Fallovo, Rouphael, Rea, Battistelli, and Colla (2009) showed similar results, in that the concentration of macronutrients in lettuce was limited even when the nutrient solution concentration exceeded a certain level.

The waste nutrient solution provided during the second cultivation period had lower EC and $\mathrm{pH}$ values compared to that during the first period, but nutrient content of curled mallows in the WNS and NS groups did not differ significantly between harvests. The average nutrient content in WNS upon second harvest was higher than that of NS for all analyzed ions, even those that were lower in upon first harvest. This could be due to a decrease in the optimum soil nutrient concentration between harvest stages, or by decreased nutrient uptake rate as the plants age (Warncke \& Barber, 1974). Edwards and Barber (1976a, 1976b) also stated that the maximum ion influx of $\mathrm{N}$ and $\mathrm{P}$ decreased with plant age. This suggests that less minerals will be needed as curled mallows age, and that use of nutrient solution during the first cultivation period and waste nutrient solution during the second 
cultivation period could be an environmentally and economically efficient approach to curled mallow cultivation, although chlorophyll content (SPAD value) and percentage dry weight may decrease compared to cultivation with nutrient solution alone (Figure 4).

Irrigation with waste nutrient solution could be an efficient way to dispose of nutrients that otherwise would leach into the environment and cause groundwater contamination. Residual soil minerals in the WNS group, which excluded minerals from commercial soil, included 80.6 and $70.0 \%$ lower $\mathrm{N}$ and $\mathrm{P}$ concentrations, respectively, compared to soil in the NS group (Table 3), while the total nutrient content of curled mallow shoots in the WNS group included 14.4 and $11.6 \%$ lower N and P concentrations, respectively, compared to the NS group during the growth period. This implies that irrigation with waste nutrient solution could result in efficient plant uptake of soil nutrients in curled mallow cultivation.

\subsection{Total Phenolic Content}

Phenolics, which contribute to antioxidant capacity, play an important role in the prevention of diseases and maintenance of health when consumed as food (La Vecchia, Altieri, \& Tavani, 2001; Tapiero, Tew, Ba, \& Mathe, 2002; P. Terry, J. Terry, \& Wolk, 2001). The total phenolic compounds in curled mallow irrigated with nutrient solution varied significantly by $11.8 \mathrm{mg} \mathrm{GAE}^{-1} \mathrm{DM}$ (milligrams of garlic acid equivalents per gram of dry matter) from those irrigated with tap water, but did not differ significantly from those irrigated with waste nutrient solution upon first harvest (Figure 5). There were no significant differences in phenolics content among the three treatments on second harvest. This suggests that irrigation with waste nutrient solution could provide as much total phenolic compounds as nutrient solution, and indicated the potential of waste nutrient solution as an irrigation solution for production of antioxidants in curled mallow cultivation.

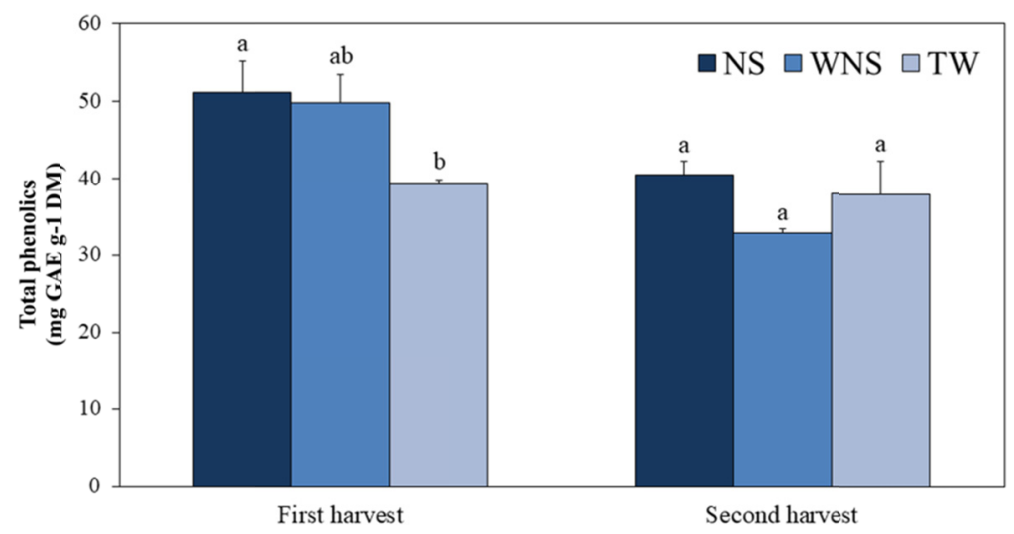

Figure 5. Content of total phenolics in curled mallows irrigated with nutrient solution, waste nutrient solution and tap water at the first and second harvest. NS: treatment with nutrient solution; WNS: treatment with waste nutrient solution; TW: treatment with tap water. Means within the same column followed by the same letter are not significantly different at the $P=0.05$ level of probability based on

Fisher's least significant difference (LSD) statistics

\section{Conclusions}

The waste nutrient solution used in this experiment was a promising alternative fertilizer for curled mallow cultivation. The yield and mineral content of curled mallow plants irrigated with waste nutrient solution were similar to plants irrigated with nutrient solution, and were significantly higher than plants irrigated with tap water. Total phenolic contents were similar in waste nutrient solution and nutrient solution treatments. Even though decrease in SPAD value and \% dry weight needs to be considered in applying waste nutrient solution, substitution with waste nutrient solution could be economically beneficial by reducing the consumption of fertilizer without significantly decreasing yield and nutritional quality. The feasibility of reusing waste nutrient solution in curled mallow cultivation could also reduce environmental pollution by preventing leaching of excess nitrogen and phosphorus into water sources and by reducing the nutrient load of agriculture. 


\section{References}

Adesemoye, A. O., Torbert, H. A., \& Kloepper, J. W. (2008). Enhanced plant nutrient use efficiency with PGPR and AMF in an integrated nutrient management system. Canadian Journal of Microbiology, 54(10), 876-886. https://doi.org/10.1139/W08-081

Badgery-Parker, J. (2002). Managing wastewater from intensive horticulture: A wetland system. Retrieved from https://www.dpi.nsw.gov.au/_data/assets/pdf_file/0005/119372/horticulture-waste-water-wetland-system-e ng.pdf

Campbell, C. (2000). Reference sufficiency ranges for plant analysis in the southern region of the United States. Southern Cooperative Series Bulletin No. 394. Retrieved from https://ag.tennessee.edu/spp/ Documents/scsb394.pdf

Chapman, S. C., \& Barreto, H. J. (1997). Using a chlorophyll meter to estimate specific leaf nitrogen of tropical maize during vegetative growth. Agronomy Journal, 89(4), 557-562. https://doi.org/10.2134/agronj1997. $00021962008900040004 x$

Choi, B. S., Lee, S. S., \& Ok, Y. S. (2011a). Effects of waste nutrient solution on growth of Chinese cabbage (Brassica campestris L.) in Korea. Korean Journal of Environmental Agriculture, 30(2), $125-131$. https://doi.org/10.5338/KJEA.2011.30.2.125

Choi, B. S., Lim, J. E., Shin, Y. K., Yang, J. E., Lee, S. S., \& Ok, Y. S. (2011b). Effect of waste nutrient solution and reclaimed wastewater on Chinese cabbage growth and soil properties. Korean Journal of Soil Science and Fertilizer, 44(3), 394-399. https://doi.org/10.7745/KJSSF.2011.44.3.394

Cirelli, G. L., Consoli, S., Licciardello, F., Aiello, R., Giuffrida, F., \& Leonardi, C. (2012). Treated municipal wastewater reuse in vegetable production. Agricultural Water Management, 104, 163-170. https://doi.org/ 10.1016/j.agwat.2011.12.011

De Rijck, G., \& Schrevens, E. (1998). Comparison of the mineral composition of twelve standard nutrient solutions. Journal of Plant Nutrition, 21(10), 2115-2125. https://doi.org/10.1080/01904169809365548

Ding, Y. C., Chang, C. R., Luo, W., Wu, Y. S., Ren, X. L., Wang, P., \& Xu, G. H. (2008). High potassium aggravates the oxidative stress induced by magnesium deficiency in rice leaves. Pedosphere, 18(3), 316-327. https://doi.org/10.1016/S1002-0160(08)60021-1

Edwards, J. H., \& Barber, S. A. (1976a). Nitrogen uptake characteristics of corn roots at low N concentration as influenced by plant age. Agronomy Journal, 68(1), 17-19. https://doi.org/10.2134/agronj1976.00021962 $006800010005 \mathrm{x}$

Edwards, J. H., \& Barber, S. A. (1976b). Phosphorus uptake rate of soybean roots as influenced by plant age, root trimming, and solution P concentration. Agronomy Journal, 68(6), 973-975. https://oi.org/10.2134/ agronj1976.00021962006800060033x

Fallovo, C., Rouphael, Y., Rea, E., Battistelli, A., \& Colla, G. (2009). Nutrient solution concentration and growing season affect yield and quality of Lactuca sativa L. var. acephala in floating raft culture. Journal of the Science of Food and Agriculture, 89(10), 1682-1689. https://doi.org/10.1002/jsfa.3641

Grasselly, D., Merlin, G., Sédilot, C., Vanel, F., Dufour, G., \& Rosso, L. (2005). Denitrification of soilless tomato crops run-off water by horizontal subsurface constructed wetlands (Vol. 691, pp. 329-332). International Conference on Sustainable Greenhouse Systems-Greensys 2004. https://doi.org/10.17660/ ActaHortic.2005.691.38

Grewal, H. S., Maheshwari, B., \& Parks, S. E. (2011). Water and nutrient use efficiency of a low-cost hydroponic greenhouse for a cucumber crop: An Australian case study. Agricultural Water Management, 98(5), 841-846. https://doi.org/10.1016/j.agwat.2010.12.010

Gutiérrez-Miceli, F. A., Santiago-Borraz, J., Molina, J. A. M., Nafate, C. C., Abud-Archila, M., Llaven, M. A. O., ... Dendooven, L. (2007). Vermicompost as a soil supplement to improve growth, yield and fruit quality of tomato (Lycopersicum esculentum). Bioresource Technology, 98(15), 2781-2786. https://doi.org/10.1016/ j.biortech.2006.02.032

Jacobson, L. (1945). Iron in the leaves and chloroplasts of some plants in relation to their chlorophyll content. Plant Physiology, 20(2), 233. https://doi.org/10.1104/pp.20.2.233 
Ju, X. T., Kou, C. L., Christie, P., Dou, Z. X., \& Zhang, F. S. (2007). Changes in the soil environment from excessive application of fertilizers and manures to two contrasting intensive cropping systems on the North China Plain. Environmental Pollution, 145(2), 497-506. https://doi.org/10.1016/j.envpol.2006.04.017

Kim, J., Kim, T., Kim, H., Lee, H., Lee, J., Lee, C., \& Paek, K. (2000). Growth and development of 'Gutbier V-10 Amy' poinsettia (Euphorbia pulcherrima willd.) as affected by application of waste nutrient solution. Korean Journal of Horticultural Science and Technology, 18(4), 518-522.

Kjeldahl, J. (1883). Neue methode zur bestimmung des stickstoffs in organischen körpern. Fresenius' Journal of Analytical Chemistry, 22(1), 366-382. https://doi.org/10.1007/BF01338151

Ko, J. H., Rodriguez, I., Joo, S. W., Kim, H. G., Lee, Y. G., Kang, T. H., \& Baek, N. I. (2019). Synergistic Effect of Two Major Components of Malva verticillata in the Recovery of Alloxan-Damaged Pancreatic Islet Cells in Zebrafish. Journal of Medicinal Food, 22(2), 196-201. https://doi.org/10.1089/jmf.2018.4235

Kumar, R. R., \& Cho, J. Y. (2014). Reuse of hydroponic waste solution. Environmental Science and Pollution Research, 21(16), 9569-9577. https://doi.org/10.1007/s11356-014-3024-3

La Vecchia, C., Altieri, A., \& Tavani, A. (2001). Vegetables, fruit, antioxidants and cancer: A review of Italian studies. European Journal of Nutrition, 40(6), 261-267. https://doi.org/10.1007/s394-001-8354-9

Medrano, E., Lorenzo, P., Sánchez-Guerrero, M. C., García, M. L., Caparrós, I., Coelho, G., \& Giménez, M. (2005). Water and nutrient use efficiency of a tomato crop as affected by two refrigeration methods: external mobile shading and fog system. Acta Horticulture, 697, 463-467. https://doi.org/10.17660/ ActaHortic.2005.697.58

Mehlich, A. (1953). Determination of P, Ca, Mg, K, Na and NH4 by North Carolina soil testing laboratories. North Carolina State University, Raleigh, North Carolina.

Mordor Intelligence. (2018). Global hydroponics market—segmented by type, crop type, and geography-growth, trends and forecasts (2018-2023). Retrieved from https://www.mordorintelligence.com/industry-reports/ hydroponics-market

Mowa, E., Akundabweni, L., Chimwamurombe, P., Oku, E., \& Mupambwa, H. A. (2017). The influence of organic manure formulated from goat manure on growth and yield of tomato (Lycopersicum esculentum). African Journal of Agricultural Research, 12(41), 3061-3067. https://doi.org/10.5897/AJAR2017.12657

Nageswara Rao, R. C., Talwar, H. S., \& Wright, G. C. (2001). Rapid assessment of specific leaf area and leaf nitrogen in peanut (Arachis hypogaea L.) using a chlorophyll meter. Journal of Agronomy and Crop Science, 186(3), 175-182. https://doi.org/10.1046/j.1439-037X.2001.00472.x

Park, C. J., Kim, K. H., Yoo, K. Y., Ok, Y. S., \& Yang, J. E. (2005). Recycling of hydroponic waste solution for red pepper (Capsicum annum L.) growth. Korean Journal of Environmental Agriculture, 24(1), 24-28. https://doi.org/10.5338/KJEA.2005.24.1.024

Park, K. W., \& Kim, Y. S. (1998). Hydroponics in horticulture. Academy book, Seoul, Korea.

Prystay, W., \& Lo, K. V. (2001). Treatment of greenhouse wastewater using constructed wetlands. Journal of Environmental Science and Health, Part B, 36(3), 341-353. https://doi.org/10.1081/PFC-100103574

Rouphael, Y., \& Colla, G. (2009). The influence of drip irrigation or subirrigation on zucchini squash grown in closed-loop substrate culture with high and low nutrient solution concentrations. HortScience, 44(2), 306-311. https://doi.org/10.21273/HORTSCI.44.2.306

Sánchez-Guerrero, M. C., Lorenzo, P., Medrano, E., Baille, A., \& Castilla, N. (2009). Effects of EC-based irrigation scheduling and $\mathrm{CO}_{2}$ enrichment on water use efficiency of a greenhouse cucumber crop. Agricultural Water Management, 96(3), 429-436. https://doi.org/10.1016/j.agwat.2008.09.001

Santos, C. V. (2004). Regulation of chlorophyll biosynthesis and degradation by salt stress in sunflower leaves. Scientia Horticulturae, 103(1), 93-99. https://doi.org/10.1016/j.scienta.2004.04.009

Savvas, D., \& Gruda, N. (2018). Application of soilless culture technologies in the modern greenhouse industry-A review. European Journal of Horticultural Science, 83(5), 280-293. https://doi.org/10.17660/ eJHS.2018/83.5.2

Savvas, D., Mantzos, N., Barouchas, P. E., Tsirogiannis, I. L., Olympios, C., \& Passam, H. C. (2007). Modelling salt accumulation by a bean crop grown in a closed hydroponic system in relation to water uptake. Scientia Horticulturae, 111(4), 311-318. https://doi.org/10.1016/j.scienta.2006.10.033 
Savvas, D., Meletiou, G., Margariti, S., Tsirogiannis, I., \& Kotsiras, A. (2005). Modeling the relationship between water uptake by cucumber and $\mathrm{NaCl}$ accumulation in a closed hydroponic system. HortScience, 40(3), 802-807. https://doi.org/10.21273/HORTSCI.40.3.802

Simpkins, D., Jungers, B. D., \& Stimmel, C. L. (2015). The soilless controlled environment agriculture (CEA) industry: hydroponics, aquaponics, issues, crop values, and market forecast through 2023. Retrieved from http://www.manifestmind.com/store/p1/Controlled_Environment_Agriculture_Report_and_Market_Forecas t_2015-2023.html

Slinkard, K., \& Singleton, V. L. (1977). Total phenol analysis: automation and comparison with manual methods. American Journal of Enology and Viticulture, 28(1), 49-55.

Steiner, A. A. (1961). A universal method for preparing nutrient solutions of a certain desired composition. Plant Soil, 15(2), 134-154. https://doi.org/10.1007/BF01347224

Tapiero, H., Tew, K. D., Ba, G. N., \& Mathe, G. (2002). Polyphenols: Do they play a role in the prevention of human pathologies? Biomedicine and Pharmacotherapy, 56(4), 200-207. https://doi.org/10.1016/S07533322(02)00178-6

Terebayashi, S., Takii, K., \& Namiki, T. (1991). Variation in diurnal uptake of water and nutrients by tomato plants of different growth stages grown in water culture. Journal of the Japanese Society for Horticultural Science, 59(4), 751-755. https://doi.org/10.2503/jjshs.59.751

Terry, P., Terry, J. B., \& Wolk, A. (2001). Fruit and vegetable consumption in the prevention of cancer: An update. Journal of Internal Medicine, 250(4), 280-290. https://doi.org/10.1111/j.1365-2796.2001.00886.x

Tüzel, I. H., Tüzel, Y., Gül, A., Meriç, M. K., Yavuz, O., \& Eltez, R. Z. (2000). Comparison of open and closed systems on yield, water and nutrient consumption and their environmental impact (Vol. 554, pp. 221-228). World Congress on Soilless Culture: Agriculture in the Coming Millennium. https://doi.org/10.17660/ ActaHortic.2001.554.23

Urbano, V. R., Mendoca, T. G., Bastos, R. G., \& Souza, C. F. (2017). Effects of treated wastewater irrigation on soil properties and lettuce yield. Agricultural Water Management, 181, 108-115. https://doi.org/10.1016/ j.agwat.2016.12.001

Van Os, E. A. (1999). Closed soilless growing systems: A sustainable solution for Dutch greenhouse horticulture. Water Science and Technology, 39(5), 105-112. https://doi.org/10.2166/wst.1999.0228

Warncke, D. D., \& Barber, S.A. (1974). Root development and nutrient uptake by corn grown in solution culture. Agronomy Journal, 66(4), 514-516. https://doi.org/10.2134/agronj1974.00021962006600040011x

Yamasaki, K., Suzuki, Y., \& Shinohara, Y. (1976). Studies on water culture of several vegetables with special reference to the control of nutrient solution and ratio of nutrients absorption per water consumption. Memoirs of the Faculty of Agriculture Tokyo University of Education, 22, 53-100.

Zekki, H., Gauthier, L., \& Gosselin, A. (1996). Growth, productivity, and mineral composition of hydroponically cultivated greenhouse tomatoes, with or without nutrient solution recycling. Journal of the American Society for Horticultural Science, 121(6), 1082-1088. https://doi.org/10.21273/JASHS.121.6.1082

Zhang, C. H., Kang, H. M., \& Kim, I. S. (2006). Effect of using waste nutrient solution fertigation on the musk melon and cucumber growth. Journal of Bio-Environment Control, 15(4), 400-405.

Zhang, C. H., Lim, Y. S., Kang, H. M., \& Kim, I. S. (2010). Effect of nutrient solution concentration on the growth and quality of paprika grown by fertigation using waste nutrient solution. Korean Journal of Horticultural Science and Technology, 28(1), 46-50.

\section{Copyrights}

Copyright for this article is retained by the author(s), with first publication rights granted to the journal.

This is an open-access article distributed under the terms and conditions of the Creative Commons Attribution license (http://creativecommons.org/licenses/by/4.0/). 